\title{
Avaliação do Estágio no Instituto Superior de Formação de Professores Salomé
}

\section{Ureña}

\section{Evaluation of Practicum at Salomé Ureña Higher Teacher Training Institute}

\author{
José Luis Reinoso Guzmán \\ University of Barcelona, Spain
}

\begin{abstract}
This research involves analyzing the role of practicum in the curriculum of initial teacher training. The goal is to show the usefulness of practicum in Preschool and Primary Education at the Salomé Ureña Higher Teacher Training Institute (ISFODOSU), in order to promote improvements in the evaluation system that entail to an educational work of higher quality, focused on the increase of the graduate's knowledge. The study has been conducted by using discussion groups, interviews and questionnaires with practicum teachers and tutors, student teachers, practicum graduates, non-practicum graduates, and school's host teachers. The research is oriented in the hermeneutic-interpretative paradigm.

Keywords: practicum, usefulness, teacher training
\end{abstract}

\section{Resumo}

Esta pesquisa tem como objetivo analisar o papel do estágio no currículo de formação inicial de professores. $\mathrm{O}$ objetivo é mostrar a utilidade do estágio no pré-escolar e ensino básico no Instituto Superior de Educação de Professores Salomé Ureña (ISFODOSU), a fim de promover melhorias o sistema de avaliação envolvendo trabalho educacional de maior qualidade, com foco na aumentar o conhecimento de graduados. O estudo foi realizado utilizando grupos focais, entrevistas $\mathrm{e}$ questionários com os professores e tutores estágio, estagiários, graduados estágio, graduados sem estágio e professores escolas de acolhimento. A investigação centra-se no paradigma hermenêutico- interpretativo.

Palabras clave: practicum, utilidade, formação de profesores

\section{Introduction}

Teacher training should be based primarily on learning from practice, with the help of an experienced teacher (Medina and Carnicero, 2009). Theoretical training is not enough to train a teaching staff with the skills for quality teaching. Therefore, the role of practicum is essential in the curriculum of initial teacher training. In it, theoretical knowledge is strengthened and practical skills are acquired. This is the premise on which this communication is based, focusing its attention on the analysis of the usefulness of practicum in Preschool and Primary Education at the Salome Ureña Higher Teacher Training Institute (ISFODOSU), in order to promote improvements in the evaluation system that entail to an educational work of higher quality, focused on the increase of the graduate's knowledge. It is also aimed to motivate the improvement of the quality of teacher training in the Dominican Republic because other colleges will be able to take the results presented and adapt them to their context. This research also analyzes other aspects of the practicum, but this communication will focus on the usefulness of practicum.

According to Schön (1983), during the educational practice there is a certain instability, ambiguity and conflict of values that theory cannot predict. Consequently, the role of practicum is the key in the initial teacher training curriculum. This training should mean the commitment to a way of working in educational spaces based on reflection, research, innovation around the problems of practices to produce innovations and improvements (Imbernón, 2007). In these practices, the future teacher integrates and gradually takes control of a classroom, assuming the teaching responsibilities. It is important that his work should be accompanied by an expert practitioner to assist him in his process of reflection and improvement of his teaching practice, as it happens at ISFODOSU. A teacher trainer and tutor accompanies the student teacher throughout the training process during practicum.

At ISFODOSU, practicum consists of 24 credits and 495 classroom hours. They are developed on two levels. The first level or pre-practicum includes three subjects: Teaching Practice I, II and III, which begin in the third semester of academic training and include observation, help and teaching interventions once a week at a school. The second level consists of Teaching Practice IV, V and VI, beginning in September of last year of training, through school insertion of student teachers during an extended school day of three days a week, at a specific grade and level, previously selected by mutual agreement between the teacher trainer and tutor, the host school teacher and the student teacher. Teaching Practice IV, V and VI is developed during a full school year in order for the future teacher to be involved in all processes that take place in an educational center of Preschool and Primary Levels, identify strengths and weaknesses in it, and develop and implement improvement plans.

This study intends to make an evaluation of practicum at Preschool and Primary Education, according to the perspectives of the actors involved in the process, in 
order to promote improvements in the evaluation system that lead to an educational work of higher quality, focused on increasing the levels of the graduate training. It is also proposed to motivate the improvement of quality of teacher training in the Dominican Republic because other colleges will be able to take the results presented and adapt them to their context. Therefore, it is of vital importance to know thoroughly the program of practicum and its implementation, for which this research was proposed to deepen in the following questions: What is the level of satisfaction of students regarding the learning they acquire during practicum? What is the usefulness of practicum for professional teaching? What improvements can be made in practicum to enhance the quality of teacher training?

\section{Method}

This research is oriented in the hermeneuticinterpretative paradigm. It advocates plurality in the evaluation of contexts and promotes a methodological orientation based mainly on qualitative methods. It seeks to promote the contextualized understanding of the program from the participants' point of view and thus create direct channels in the improvement of a program (Sandín, 2003). Medina, Jarauta and Urquizu (2006) also propose to evaluate programs from the interpretative paradigm, taking into account the point of view of people who have been subjects of the formative action. What is interesting is to know the phenomena as they are lived by participants and in the contexts in which they take place.

\section{Participants}

Participants in this research were the four groups of actors who make practicum possible: teacher trainers and tutors, host school teachers, student teachers, and practicum graduates. The researcher decided to include graduates from colleges without practicum to have the points of view of those who don't have the experience of a practicum. A questionnaire with open questions was applied to all actors in the practicum process.

\section{Instruments}

The data collection techniques used were the discussion group, the interview and the questionnaire. Two discussion groups were held, one with the practicum coordinator and the current and previous teacher trainers and tutors. The other discussion group consisted of members among student teachers and practicum graduates.

\section{Procedure}

In this research, an attempt was made to reach as many participants as possible in order to do a detailed and in-depth analysis. All participants were volunteers. They were explained that it was anonymous and voluntary information. All active teacher trainers and tutors during the three weeks of the field work participated in filling out the questionnaire. About half the student teachers participated in the questionnaire. Participants in discussion groups and in interviews were chosen according to the availability and willingness to participate. All ten schools where practicum was being held during school year 2016-2017 were chosen for the study. The information was collected at ISFODOSU campus Emilio Prud'Homme and those 10 schools in Santiago de los Caballeros, Dominican Republic during the month of April of 2017. For qualitative analysis of information, the software Atlas Ti, version 7 was used. In this communication, a preliminary analysis of the information is presented.

\section{Results and discussion}

\section{Expectations versus satisfaction}

As a way of evaluating the usefulness of practicum according to the perspectives of the agents involved in this study, it was proposed to explore the expectations of student teachers and practicum graduates before entering their education career and to know the extent to which these expectations were met. The information analysis shows a notable satisfaction with practicum. Both student teachers and practicum graduates indicated that their expectations were met and even exceeded. The researcher of this study conducted himself discussion groups and interviews. Emotion can be seen in many of the answers offered. These instruments captured the participant's feelings, while at the same time the presence of empathy with the educational center where they were being trained as teachers or where they got their degree. They said they felt proud to have studied at ISFODOSU. They thanked the teachers not only for the academic knowledge, but also for the values they got: "I learned during that year things for life", to be "counselor, psychologist, a human being." "I had the desire to be a teacher, I entered the ISFODOSU with that purpose, but when I began practicum that I saw reality, I fell in love completely". "Practicum makes you change a lot, you become that teacher children need". "Practicum made me grow up as a teacher and as a professional." "What each of you (student trainers) taught me I have been able to apply in my two years as a teacher and I have not let the Institute down".

The main expectations, according to practicum graduates were developing methodological strategies for good classroom management, learning to be a proactive and motivating teacher, and creating a foundation for their professional teacher development. They said their expectations had been met. Student teachers agree with the expectations indicated by practicum graduates. When asked if these expectations were met, they said they had been "covered to a great extent, since each day that passes I feel more with the capacity of an excellent teacher and I have learned to be more than dynamic in the course of practicum". "They are being covered by practice at school." We are getting "new knowledge that is making us grow as people." "I have learned to use the resources necessary for a good teaching practice." "I have put into action the theoretical knowledge that I acquired at ISFODOSU". "We have acquired the experience through contact with different public schools for a period of approximately three months." 
Participation in this research was voluntary. All practitioners who participated are satisfied with practicum. The analysis of the answers offered in the discussion groups, interviews and questionnaires shows an agreement, an idea in common. Practicum graduates and student teachers agreed in affirming that practicum has made a great impact on them and has motivated them to continue their research on different topics they need to work on during their classroom practices. They emphasized the importance of using various methodological strategies that they learned from practicum. They highlighted the need for practicum in the teacher training program because as they said it is where the student teacher realizes if he has the calling to be a teacher. They said they felt great satisfaction because they discovered what they wanted to do in life. The satisfaction of student teachers and practicum graduates is perceived as a thank you to the training received by their teacher trainers not only in terms of good classroom management, but also in personal aspects. Many of them, prior to practicum, had difficulties, such as low self-esteem, scenic fear, and disinterest in teaching profession. However, practicum has motivated them and has helped them to feel better about themselves by feeling useful with the teaching work when noticing the learning of children at educational centers. A large number of students have decided to study at ISFODOSU for situations that are not the most suitable ones. These include the full scholarship granted to them, the snack and breakfast given to them every day, financial aid from the second semester, difficulty in entering another career because it is very expensive or because they have not passed the exam. In spite of everything, most end up feeling very comfortable with the teaching career and that is due in large part to the experience they lived during practicum.

\section{Usefulness of practicum for professional teaching}

The primary goal of this study was to determine whether practicum was useful for professional practice of teachers. As for this inquiry, student teachers, practicum graduates, teacher trainers and tutors and host school teachers responded in the affirmative. They agreed that practicum laid the foundation for the professional future of graduates as teachers; in the process they faced educational and social reality, which will be useful for their future professional performance and allowed them to put into practical context the theoretical knowledge they learned at the Institute.

Practicum graduates agreed with teacher trainers and tutors and host school teachers as to the usefulness to learn to face and solve situations of classroom conflicts, to respond to unexpected situations and to have a good group management. Teacher trainers and tutors and host school teachers agreed that practicum allows practitioners to implement a variety of strategies during their practices. Student teachers and teacher trainers and tutors agreed that skills are acquired to do effective work as a teacher and it is a way to bring students to the context where they will carry out their profession. Practicum graduates indicated that practicum allowed them to learn from the most experienced teachers and get in touch with all the processes of an educational institution where different actors interact (principal, administrative staff, support staff, parents).

Student teachers indicated that practicum works as a sponge to absorb all the good from teaching practice. Many skills are acquired during practice and then carried out as a professional teacher. When a teacher begins his professional teaching life, he already has the professional experience acquired through his practicum. Teacher trainers and tutors indicated that professionals do not feel afraid to carry out their profession, as they take their classes very easily by having lived the experience of their profession during practicum. Student teachers learn the matters of working with students. Practicum empowers prospective teachers to perform efficiently. Practicum is useful because if student teachers do not blend with reality, they do not develop the pedagogical and personal skills that a good teacher should have. Host school teachers said that practicum helps student teachers to train as qualified, critical and reflective teachers, enabling them to improve and grow professionally.

Information analysis reveals that the four groups of practicum actors justified the usefulness of practicum indicating the different elements that make practicum the transversal axis of the teaching career. They cannot imagine a teacher graduate without having experienced first-hand the one year of practicum they had.

\section{Evaluation and suggestions for improvement}

Positive aspects of practicum. Inquiries regarding the participants' assessment of practicum showed relevant information that has helped to complement their previous opinions. In addition, they have provided firsthand information on key elements to produce improvements in implementing practicum. The analysis of information shows a highly positive evaluation of practicum by participants, which indicates a high level of satisfaction by the four groups of actors included in this study which identified as positive aspects the implementation of theoretical knowledge from College, the development of competences to face the real situations of a classroom, the use of appropriate methodological strategies for a good classroom management and reflection on educational practice in order to improve teaching.

Practicum graduates, student teachers and host school teachers agreed on the responsibility of student teachers in their performance, creativity and innovation during teaching. Practicum graduates and teacher trainers and tutors agreed that practicum helps student teachers learn to handle and confront situations of conflict in the classroom. Practicum graduates and host school teachers agreed on the management of competencies proposed by curriculum design of Preschool and Primary Education to provide teaching and teamwork by student teachers. Teacher trainers and tutors and host school teachers agreed on the use of materials by student teachers in the classroom. They use a variety of materials which are not commonly used by Preschool and Primary School teachers.

Student teachers and host school teachers agreed to indicate the control and management of groups by student teachers in the classroom. Practicum graduates 
included as positive elements of practicum empathy among actors, especially among student teachers and children, understanding the evaluation system of student teachers, adaptation of student teachers to work in educational centers, the opportunity to exercise leadership, the application of relevant teaching-learning strategies, the planning and execution of improvement projects according to the needs of students, the student teachers' involvement in school life, the good tutoring and continuous accompaniment by the teacher trainer and tutor, the development of skills, teacher training, support and availability of resources at schools.

Teacher trainers and tutors pointed out as positive elements of practicum the development of classroom strategies and techniques, student teachers follow the suggestions coming from host school teachers and teacher trainers and tutors, the coordination of practicum provides the key guidelines for the actors of practicum, learning is improving at schools by implementing action research methodology, attention to diversity by student teachers, integration of different actors of the educational community in the development of the processes of the teaching practice and the strengthening of the relationship among the Institute and educational centers through workshops and talks. Host school teachers indicated that student teachers learn to manage a classroom, they integrate in all school activities, use adequate resources, interest in their work, students are more active to participate in classes, practicum allows host school teachers and student teachers to share knowledge and experiences, and student teachers learn to use new methodologies.

Missing aspects and suggestions. Practicum graduates, student teachers, teacher trainers and tutors and host school teachers agreed that subjects should be reorganized so that student teachers could have more time to perform their practices. Practicum graduates and teacher trainers and tutors pointed out that in addition to the teacher trainers and tutors and host school teachers, it is necessary the point of view of other teachers specialized in the curricular area of concentration of practicum teacher to support the process of practicum. Student teachers and teacher trainers and tutors agreed that workshops should be offered as reinforcement before they begin practicums to have this prior knowledge and to be able to use it during practice. In addition, teacher trainers and tutors should have more free time to give more follow-up to the student teachers and more time to socialize and reflect on practicum.

The host school teachers indicated at this point that teacher trainers and tutors should give more follow-up to the student teachers. Student teachers pointed out that for evaluation, teacher trainers and tutors should not only take into account a good research work but what is achieved or improved in a classroom with students. They indicated that accompaniment of student teachers by teacher trainers should be improved, so they give them more suggestions and help them improve their performance at school centers. Teacher trainers and tutors said that class modeling by teacher trainers and tutors should be included during the process of practicum, techniques for working with diversity, greater economic investment and human resources, articulation between teaching practice and other curricular areas, vehicles available so student teachers are taken to and from schools, teaching resources available for student teachers so they can take them to school and use them in their classes, inclusion of a certain amount of books that student teachers must read: growth books, pedagogy, personal training, among others, and economic incentives for student teachers and teacher trainers to be more motivated to do their work.

Host school teachers pointed out the need for student teachers to teach classes in different areas during their practicum because their degree is in Primary School and when they are professionals they will have to teach all subjects, more workshops or subjects that favor and strengthen student teachers' knowledge in Spanish. Before they begin their practices, have them learn a good writing on the board. Have one student teacher per classroom because three of them per classroom are too much. This last aspect, having a single practitioner per classroom, has been changed in the last school year. In previous years, there was always only one practitioner per classroom. Only three student teachers worked together to offer a workshop to students while implementing their projects. It is obvious that this change is detrimental to the training of student teachers, since their teaching hours have been considerably reduced. Now they must share the teaching time with their other two colleagues. In addition, when working in extended class, the subjects of Mathematics and Spanish Language consist of two hours of duration, instead of one hour. This reduces even more the opportunities to play the role of teachers.

\section{Evaluation of college graduates without practicum}

For the evaluation of a practicum program, it is essential, as it has been done, to take into account the participants in the process: student teachers, teacher trainers and tutors, host school teachers and practicum graduates. In this study, it was decided to include college graduates who did not have practicum in their training program. They offered valuable information about the importance of having a practicum and the vicissitudes encountered when one does not have it. Information analysis reveals that graduates without practicum were based on different situations that differ from the experiences acquired by those who had practicum.

As for the aspects that have helped them in their professional teacher training, they included the responsibility assuming the role of a teacher, sensitivity in practice with an attitude of solidarity at school in compliance with attention to diversity, perseverance, love for what they do, dedication to study the contents, being punctual in the arrival at the center and the classroom, innovation and updating through lectures, diplomas, workshops and other studies and accompaniments in the classroom.

Graduates from colleges other than ISFODOSU pointed out that the main difficulties they faced during the first year of professional teacher work were problems in planning and working with the degree register, 
difficulties in handling the discipline of children with behavioral and learning problems, complications to confront works in groups of students, use of inappropriate or non-functional strategies in the classroom. They said it was a process of adaptation teacher-student and other colleagues of the educational center. They were asked how they had acquired the methodological strategies, classroom management, content management, and use of curriculum for their teaching performance. Their answers were: through study of brochures and books at college, with co-workers and the support of the coordinators, through training workshops, reading books, short courses and through daily practice, through years of teaching and the use of technology.

They considered that having had a practicum would have been useful for their academic and professional training as teachers because it is where you acquire the practical skills that prepare you to be a teacher, because in practice you reinforce your skills and you learn new things. A practicum would have been very useful because they would have acquired the experience to make a better work from the beginning of their professional career. They said that throughout their college studies they only performed one or two practices without supervision, which were not enough for academic training. The affirmations of the graduates confirmed the relevance of the inclusion of a good program of practicum in the teacher training.

\section{References}

Imbernón, F. (2007). La formación y el desarrollo profesional del profesorado. Hacia una nueva cultura profesional. Barcelona: Graó.

Instituto Superior de Formación Docente Salome Ureña (ISFODOSU) (2013). Área de Práctica y Pasantía Profesional. Sistema de Práctica y Pasantía Profesional. Santo Domingo, 2013. URL: https://docs.google.com/viewer?a=v\&pid=sites\&srcid $=$ ZGVmYXVsdGRvbWFpbnxjb211bmlkYWR2aXJ0 dWFsaXNmb2Rvc3V8Z3g6M2UyMzI3NGQxMGJm $\mathrm{NjRjZg}$

Medina, J.L., Jarauta, B. y Urquizu, C. ((2006). Evaluación del impacto de la formación del profesorado universitario novel: un estudio cualitativo. Barcelona: Universidad de Barcelona. FODIP.

Medina, J.L. y Carnicero, P. (2009). La formación inicial de docentes para la Educación Primaria en la Región Centroamericana y República Dominicana. Análisis de la situación y propuestas para convergencia regional. Colección IDER. http://www.oei.es/noticias/spip.php?article5654

MESCyT (2015). Normativa 9-2015 para la Formación Docente de Calidad en la República Dominicana. Santo Domingo: MESCyT.

Sandin, M. (2003). Investigación Cualitativa en Educación. Fundamentos y tradiciones. Madrid: McGrawHill.
Schön, D. (1983). The reflective student teachers: How Professionals Think in Action. New York: Basic Books. 